\begin{tabular}{l|l|l} 
Jurnal Eksplorasi Akuntansi & $\begin{array}{l}\text { Vol. 2, No 1, Seri C, Februari 2020, Hal 2348-2361 } \\
\text { ISSN : 2656-3649 (Online) } \\
\text { http://jea.ppj.unp.ac.id/index.php/jea/issue/view/19 }\end{array}$
\end{tabular}

\title{
PENGARUH PENDAPATAN ASLI DAERAH DAN BELANJA MODAL TERHADAP TINGKAT KEMANDIRIAN KEUANGAN DAERAH DENGAN PERTUMBUHAN EKONOMI SEBAGAI VARIABEL MODERATING
} (Studi Empiris Pada Kabupaten/Kota di Provinsi Sumatera Barat Tahun 2015-2018)

\author{
Tri Utari Handayani ${ }^{1}$, Erinos ${ }^{2}$ \\ ${ }^{1}$ Alumni Jurusan Akuntansi Fakultas Ekonomi Universitas Negeri Padang \\ ${ }^{2}$ Jurusan Akuntansi Fakultas Ekonomi Universitas Negeri Padang \\ *Korespondensi: triutarihandayani14@gmail.com
}

\begin{abstract}
Abstrack: This study aims to examine the effect of regional original income and capital expenditure on regional financial independence with economic growth as a moderating variable. The sample used in this study is the district / city of West Sumatra Province with a sampling method that is total sampling, so that a sample of 12 districts and 7 cities in West Sumatra is obtained. This study uses multiple regression data analysis techniques and residual tests for moderating tests. The results showed that the original regional income had a significant positive effect on regional financial independence, although the effect was only 8.1\%. Capital expenditure does not affect the financial independence of the region and economic growth cannot moderate the relationship between the region's original income and capital expenditure to the financial independence of the region.
\end{abstract}

Keywords: Capital expenditure; Economic growth; Intergovernmental transfer; Local revenue; The level of local independence

How to cite (APA $6^{\text {th }}$ style):

Handayani, T.U \& Erinos. (2019). Pengaruh Pendapatan Asli Daerah Dan Belanja Modal Terhadap Tingkat Kemandirian Keuangan Daerah Dengan Pertumbuhan Ekonomi Sebagai Variabel Moderating (Studi Empiris Pada Kabupaten/Kota di Provinsi Sumatera Barat Tahun 2015-2018). Jurnal Eksplorasi Akuntansi. 2(1), Seri C, 2348-2361.

\section{PENDAHULUAN}

Reformasi yang terjadi tanggal 1 januari 2001 terhadap manajemen keuangan berupa pelaksanaan desentralisasi fiskal dan otonomi daerah. Pengelolaan keuangan daerah tanpa kewenangan pemerintah pusat untuk mengatur merupakan dampak dari dilaksanakannya otonomi daerah, dimana pengelolaan harus disesuaikan pada kebutuhan daerah. Pelaksanaan ini dilakukan agar dapat terjadinya peningkatan kemandirian keuangan daerah dengan begitu 
ketergantungan terhadap keuangan pemerintah pusat bisa berkurang (Mahmudi,2010:2).

Optimalnya kualitas pelayanan pemerintah pada masyarakat, seperti cukup berkualitasya layanan umum dan layanan sosial, adanya perbaikan dan penambahana infrastrktur, bagunan, peralatan, serta tersedianya pelayanan kesehatan dan pendidikan yang memadai membuat kesejahteraan masyarakat meningkat. Terpenuhinya kegiatan di atas yang merupakan bentuk dari belanja modal dengan pendapatan daerah sendiri maka dapat dikatakan mandiri daerah tersebut (Halim, 2007).

Permasalahan kemandrian keuangan daerah yang merupakan tujuan desentralsasi fiskal dan otonomi sudah lama terjadi pada banyak negara. Otonomi fiskal pemerintah daerah di Korea serta hubungan antar pemerintah pada tahun 1990-an yang diteliti Kim dan Young (2003) berfokus pada keuangan fiskal, administrasi dan sentralisasi politik. Koo dan Kim (2018) meneliti dua wajah desentralisasi di Korea Selatan yang berfokus pada gambaran desentralisasi di Korea Selatan dengan tiga perspektif yang berbeda yaitu perspektif politik, administrasi dan keuangan fiskal. Di Albania terjadi modernisasi pemeintah daerah diteliti Guga (2018) dengan fokus penelitiannya pada keseluruhan proses desentralisasi terhadap reformasi reformasi administrasi-teritorial.

Penelitian Kim dan Young (2003), Koo dan Kim (2018), Guga (2018) menmukan bahwa adanya ketergantungan yang sangat tinggi pemerintah daerah Korea dan Albania dalam melaksanakan kegiatan pemerintahan pada transfer keunagan pemerintah pusat. Di Albania pemerntah daerah menerima pendaptan dari pemerintah pusat sebesar $90 \%$ dari pendapatannya. Pendapatan daerah di tahun 2015 hanaya 4\% dari total pendapatannya, sementara lebih dri dua kali pendapatan pajak yang dikumpulkan dbelanjakan daerah (Guga,2018). Kim dan Young (2018) menyebutkan bahwa pemerintah daerah di Korea memiliki ketergantungan yang lebih parah terhadap keuangan pemerntah pusat dibandingkan negara industri lainnya. Dibeberapa daerah pedesaan, pemda hanya dapat menghasilkan $10 \%$ pendapatan mereka dari pajak.

Penelitian Purbadharmaja et al (2018) berfokus pada implikasi desentralisasi fiskal dan tata kelola anggaran pada kapasitas ekonomi dan kesejahteraan masyarakat Bali di Indonesia menemukan bahwadalam desentralisasi fiskal terjadi kenaika transfer keuangan pemerintah pusat (DAU) mengartikan ketergantungan yang tinggi dari pemerintah daerah. Banyaknya anggaran dari pusat membuat peran eksekusi desentralisasi fiskal melemah, karena pembiayaan hanay mengandalkan DAU dari pada menggunakan PAD sendiri.

Sejumlah penelitian seblumnya yang ada Indonesia menyebutkan faktor yang mempengruhi kemandirian keuangan daerah diantaranya Belanja Modal dan Belanja Pegawai (Darwis, 2015), Pendapatan Asli Daerah, Dana Bagi Hasil, Dana Alokasi Umum, dan Dana Alokasi Khusus (Sanga et al, 2018), Pertumbuhan Ekonomi dan PAD (Tolosang, 2018), Likuiditas, Leverage,Ukuran dan Kemakmuran (Firmansyah, 2017).

Penelitian ini menggunakan variabel Pendapatan Asli Daerah dan variabel Belanja Modal karena peneliti menganggap faktor ini paling mampu mendiskripsikan kesanggupan pemerintah daerah dalam membiayai pemerntahsendiri, pembangunan maupun pelayananpada masyarakat. Penelitian yang sebelumnya (Apriana dan Suryanto ,2010; Nur'ainy et al,2013; Yuliyanto,2018; Tahar dan Zakhiya,2011) Pendapatan Asli Daerah dan Belanja Modal diukur dari realisasinya, namun penelitian ini pengukuran brdasarkan proporsinya dan belanja modal dari rasio keserasian. Hal ini dilakukan untuk menjawab keterbatasan dalam penelitian Tahar dan Zakhiya (2011) bahwa variabel PAD memiliki pengaruh terhadap kemandirian keuangan daerah, dimana pada penelitiannya pengukuran kemandirian daerah yaitu perbandingan PAD dengan total pendapatan daerah, sehingga timbulnya tautologi pada penelitiannya yaitu PAD terhadap PAD. 
Berdasarkan latar belakang yang dipaparkan diatas, maka penulis memilih untuk mengangkat judul penelitian "Pengaruh Pendapatan Asli Daera dan Belanja Modal dengan Pertumbuhan Ekonomi sebagai Variabel Moderating pada Kabupaten/Kota Provinsi Sumatera Barat" tahun 2015 sampai dengan tahun 2018.

\section{REVIU LITERATUR DAN PENGEMBANGAN HIPOTESIS Teori Keagenan}

Stewardship Theory ini disebut juga sebagai teori pengelolaann yangmenjelaskan ketika seorang manajer bertindak sesuai dengnan tanggung jawabnya dengan lebih mengupayakan keinginan serta kepentingan prinsipal dibandingkan kepentingan dirinya sendiri, bersikap jujur dan berintergritas kepada pihak lain (Davis dan Donalson, 1991).Teori Stewardship ini melihat bagaimanaseorang manajemen di sebuah organisasidiasumsikan sebagai stewards yang bekerja dengan integritas dan penuh tanggung jawab berdasarkan tujuan organisasi (Sanga et al, 2018).

\section{Tingkat Kemandirian Keuangan Daerah}

Besar kecil pendapatan daerah dari pembayaran pajak dan retribusi oleh masyarakat berdampak pada kesanggupan pemerintah daerah dalam mendanai pemerintahannya sendiri seperti pembangunan dan pelayanan pada masyarakat sehingga dapat diketaui tingkat kemandirian keuangan daerah (Halim,2007).

\section{Pertumbuhan Ekonomi}

Pada perekonomian daerah salah satu yang menjadi indikator keberhasilan pembangunan dapat dilihat dari pertumbuhan ekonominya. Besarnya perubahan pertumbuhan dari hasil regulasi nasional menentukan kemajuan perekonomian suatu daerh. Penngkatan faktor-faktor produksi menjadi kesempatan bagi daerah agar pertumbuhan ekonomi dapat meningkat yang menyebabkan pendapatan daerah juga dapat mengalami peningkatan (Sukirno, 2002).

\section{Pendapatan Asli Daerah}

Pendapatan Asli Daerah berdasarkan Undanng-Undang Nomor 33 Tahun 2004 tentang Perimbangan Keuangan antara Pusat dan Daerah Pasal 1 angka 18 yaitu adalah pendapatan yang dipungut atau diperoleh daerah sesuai peraturan perundang-undangan.PendapatanAsli Daerah (PAD) merupakan penerimaan daerah sendiri harus terus ditingkatkan untuk dapat membantu dalam memikul beban biaya yang diperlukan dalamterselenggaranya aktifitas pemerintah dan semakin meningkat, sehingga kemandirian yang merupakan tujuan otonomi daerah dapat dilaksanakan.

\section{Belanja Modal}

Pengeluaran anggaran agar mendapatkan aset tetap dan aset lainnya yang dapat memberikan manfaat lebih dari satu periode akuntansi disebut sebagai belanja modal. Alokasi anggaran belanja modal didasarkan pada kebutuhan daerah terhadap sarana dan prasarana, yang digunakan untuk melancarkan tugas pemerintahandan untuk fasilitas publik.

\section{Pengaruh Pendapatan Asli Daerah terhadap Tingkat Kemandirian Keuangan Daerah}

Pengukuran kemandirian keuangan daerah dapat dilihat dari besaran sumber pendapatan asli daerah karena pendapatan ini menggambarkan bagaimana keadaan potensi riil suatu daerah (Muliana dalam Yuliyanto, 2018). Keuangan pemerintah daerah yang bergantung dengan 
keuangan pemerintah pusat menyebabkan rendahnya kemandirian keuangan daerah. Halim (2007:284) memberikan pandangan bahwa besaran pendapatan yang diperoleh lansung daerh akan berdampak pada tingkat kemandirian keuangan suatu daerah.

Konsisten dengan penelitian Apriana dan Sutyanto (2010) dan Sanga, Hermanto dan Handayani (2018) menemukankemandirian keuangan daerah diperngaruhi secara positif oleh pendapatan asli daerah, maka dari itupeneliti dapat merumuskan hipotesis pertama adalah sebagai berikut :

H1 :Pendapatan Asli Daerah berpengaruh signifikan positif terhadap Kemandirian Keuangan Daerah.

\section{Pengaruh Belanja Modal terhadap Tingkat Kemandirian Keuangan Daerah}

Sumber pendapatan daerah harus terus dapat ditingkatkan dalam pelaksanaan otonomi daerah karena akan diperlukan untuk mendanai kegiatan pemerntahan dalam bentuk belanja modal dan belanja operasi, banyaknya belanja modal yang dibiayai oleh keungan daerah menunjukan daerah tersebut dapat menjalankan pemerintahannya.

Pelayanan publik yang dapat ditingkatkan oleh pemerntah daerah dalam bentuk belanja modal dari pendaptan daerah dibandingkan dari keuangan pemerntah pusat seperti DAU maupun DAK mengartikan bahwa pendapatan daerah sendiri telah mencukupi untuk mendanai pemerintahannya. Konsisten denganAriani dan Putri (2010) danDarwis (2015) yang menemukan Kemandirian Keuangan Daerah diperngaruhui secara positif oleh belanja moda., maka dari itu peneliti dapat merumuskan hipotesis kedua sebagai berikut :

H2: Belanja Modal berpengaruh signifikan positif terhadap Kemandirian Keuangan Daerah.

\section{Pengaruh Pendapatan Asli Daerah dan Belanja Modal terhadap Tingkat Kemandirian Keuangan Daerah dengan dimoderasi oleh Pertumbuhan Ekonomi}

Peningkatan pertumbuhan ekonomi pada suatu daerah maka dapat meningkatkan Pendapatan Asli Daerah dan belanja modal sehingga pendapatan yang diperoleh masyarakat yang semakin meningkat mengindikasi bahwa kemampuannya masyarakat untuk membayar pungutan yang ditetapkan oleh pemda juga akan meningkat.

Pertumbuhan ekonomi yang mengalami peningkatan bersamaan dengan kenaikan pendapatan asli daerah diharapkan kemampuan daerah dalam pelaksanaan otonomi dapat terpenuhi dengan begitu kemandirian keuangan daerah akan semakin baik ataupun ketergantungan daerah terhadap keuangan dari pemerintah pusat akan semakin berkurang. Berdasarkan dari penelitian yang dilakukan Nur'ainy, Desfitria dan Utomo (2013) menemukan bahwa pertumbuhan ekonomi berpengaruh terhadap kemandirian keuangan daerah.

H3: Pertumbuhan ekonomi memoderasi pendapatan asli daerah dan belanja modal terhadap kemandirian keuangan daerah

\section{METODE PENELITIAN}

\section{Jenis Penelitian}

Penelitian ini termasuk ke dalam penelitian kausatif, dimana tujuannya untuk menganalisis seberapa besar variabel bebas dapat mempengaruhi variabel terikat, dan bagaimana pengaruhnya. 


\section{Populasi dan Sampel}

Populasi penelitian ini adalah 12 kabupaten dan 7 kota yang terdapat di Provinsi Sumatera Barat tahun 2015 sampai dengan 2018.Sampel penelitian ditentukan menggunakan teknik sampel jenuh, dimana seluruh populasi penelitian dijadikan sebagai sampel.

\section{Jenis dan Sumber Data}

Data penelitian tergolong dalam jenis data sekunder berupa laporan realiasi APBD yang telah diperiksa oleh BPK RI unit Sumbar dan data Pertumbuhan Ekonomi (Produk Domestik Regional Bruto atas dasar harga konstan) Pemerintah Kabupaten/Kota di Provinsi Sumatera Barat dari tahun 2015 sampai dengan 2018.

\section{Variabel Penelitian dan Pengukurannya}

\section{Tingkat Kemandirian Keuangan Daerah}

Rasio kemandirian keuangan daerah diukur dengan rumus dibawah ini :

Rasio Kemandirian $=\frac{\text { Pendapatan Asli Daerah }}{\text { Bantuan Pusat dan Pinjaman }} \times 100 \%$

\section{Pertumbuhan Ekonomi}

Pertumbuhan ekonomi pada penelitian ini dihitung untuk menggambarkan pertumbuhan riil dari sektor ekonomi dari tahun ke tahun menggunakan PDRB atas dasar harga konstan.

Pertumbuhan Ekonomi $=\frac{\text { PDRB }_{t}-\text { PDRB }_{t-1}}{\text { PDRB }_{t-1}} \times 100 \%$

\section{Pendapatan Asli Daerah}

Penelitian ini PAD diukur dengan melihat besarnya realisasi PAD dibandingkan total pendapatan daerah dalam laporan Realisasi APBD Kabupaten/kota

\section{Belanja Modal}

Penelitian ini Belanja modal diukur dengan melihat besarnya realisasi PAD dibandingkan total belanja daerah dalam laporan Realisasi APBD Kabupaten/kota.

\section{TEKNIK ANALISIS DATA}

\section{Analisis Deskriptif}

Teknik deskriptif yang dimaksudkan dalam penelitian ini adalah untuk menginterprestasikan besarnya nilai maksimum, minimum, mean, median dan standar deviasi dari masing-masing variabel dalam penelitian.

\section{Analisis Regresi Berganda}

Analisis regresi berganda ini tujuannya untuk mengatahui hubungan variabel terikat dengan variabel bebas.Persamaan regresi berganda sebagai berikut: 


$$
\gamma=\alpha+\beta 1 X 1+\beta 2 X 2+e
$$

Keterangan :

$\mathrm{Y}=$ Kemandirian Keuangan Daerah

$\alpha=$ Konstanta

$\beta=$ Koefisien dari Pendapatan Asli Daerah

$\mathrm{X}_{1}=\mathrm{PAD}$

$\beta=$ Koefisien dari Belanja Modal

$\mathrm{X}_{2}=$ Belanja Modal

$\varepsilon=$ error

\section{Analisis Regresi Variabel Moderating}

Variabel moderating diuji dengan uji residual. Berdasarkan spesifikasi model regresi menggunakan variabel moderating maka model persamaan dalam penelitiaan ini menggunakan rumus Ghozali (2006: 171) adalah sebagai berikut:

$\mathrm{PE}=\alpha+\beta 1 X 1+\beta 2 X 2+e$

$|\mathrm{e}|=\alpha+\beta 3 \gamma$

Keterangan :

PE : Pemoderasi (Pertumbuhan Ekonomi)

A : Koefisien Konstanta

$\beta 1-\beta 2$ : Koefisien Regresi

X1 : Belanja Modal

X2 : Pendapatan Asli Daerah

Y : Kemandirian Keuangan Daerah

e : : Error term

$|\mathrm{e}| \quad$ : Nilai residual mutlak

\section{HASIL DAN PEMBAHASAN}

Bagian ini menguraikan hasil pengujian pendapatan asli daerah dan belanja modal terhadap kemandirian keuangan daerah dan dengan dimoderasi oleh pertumbuhan ekonomi.

\section{Statistik Deskriptif}

Tabel 1

Statistik Deskriptif

Descriptive Statistics

\begin{tabular}{lcrrrr}
\hline \multicolumn{7}{c}{ Descriptive Statistics } \\
\hline & $\mathrm{N}$ & \multicolumn{1}{c}{ Minimum } & Maximum & \multicolumn{1}{l}{ Mean } & \multicolumn{1}{c}{ Std. Deviation } \\
\hline PAD & 76 & -3.077 & -1.339 & -2.42639 & .387758 \\
\hline Belanja Modal & 76 & -2.125 & -1.055 & -1.50473 & .258953 \\
\hline Pertumbuhan Ekonomi & 76 & -3.007 & -1.022 & -2.30306 & .432925 \\
\hline Kemandirian Keuangan & 76 & -3.110 & -2.744 & -2.89645 & .073577 \\
Daerah & 76 & & & & \\
\hline Valid N (listwise) & 76 & & &
\end{tabular}

Sumber : Data Olahan SPSS 25 tahun 2020 
Tabel 1 menyajikan statistik deskriptif penelitian untuk melihat nilai maksimum, minimum, mean, median dan standar deviasi dari masing-masing variabel penelitian.

\section{Uji Asumsi Klasik}

Uji Normalitas

Pengujian ini tujuannya untuk melihat data dari variabel independen dan variabel dependen apakah berdistribusi normal. Penelitian ini menggunakan pengujian Kolmogorov Smirnov Testuntuk menguji normalitas data variabel.

Tabel 2

Hasil Uji Nornalitas

\begin{tabular}{llr}
\hline \multicolumn{3}{c}{ One-Sample Kolmogorov-Smirnov Test } \\
\hline $\mathrm{N}$ & $\begin{array}{c}\text { Unstandardized } \\
\text { Residual }\end{array}$ \\
\hline Normal Parameters $^{\mathrm{a}}$ & Mean & 76 \\
\cline { 2 - 3 } & Std. Deviation & .0000000 \\
\hline Most Extreme Differences & Absolute & .06543017 \\
\cline { 2 - 3 } & Positive & .075 \\
\cline { 2 - 3 } & Negative & .043 \\
\hline Kolmogorov-Smirnov Z & & .075 \\
\hline Asymp. Sig. (2-tailed) & & .783 \\
\hline a. Test distribution is Normal. & & \\
\hline
\end{tabular}

Sumber : Data Olahan SPSS 25 tahun 2020

Hasil pengujian Kolmogorov Smirnov pada tabel 2, dapat peneliti simpulkan bahwa data variabel mempunyai distribusi normal karena ditunjukkan oleh nilai Asymp. Sig. (2-tailed) adalah 0.783. Nilai Asymp. Sig. (2-tailed) pada tabel 4.6 lebih besar dari 0.05, maka dinyatakan data variabel mempunyai distribusi yang normal.

\section{Uji Multikolinearitas}

Pengujian initujuannya untuk mengetahui terdapat atau tidaknya korelasi antara variabelvariabelindipenden pada penelitian ini. Penelitian ini menggunakan pengujian Variance Inflation Factor (VIF) dan Tolerance Valueuntuk menguji korelasi variabel, jika hasil VIF yang didapatkan diatas atau besar dari 10 dan $\mathrm{TF}$ dibawah atau kecil dari 0,10 maka multikolinearitas terjadi pada penelitian ini.

Tabel 3

\section{Hasil Uji Multikolinearitas}

\begin{tabular}{l|r|r} 
& \multicolumn{2}{|c}{ Collinearity Statistics } \\
Model & Tolerance & VIF \\
\hline (Constant) & .970 & 1.031 \\
\hline PAD & .970 & 1.031 \\
\hline BelanjaModal & & \\
\hline
\end{tabular}

a. Dependent Variable: KemandirianKeuanganDaerah 
Hasil pengujian tabel 3, terdapat bahwa perhitungan nilai tolerance untuk variabel PAD (X1) sebesar 0.970 dan nilai VIF nya sebesar 1.031. Belanja Modal (X2) mendapatkan nilai tolerance sebesar 0.970 dan nilai VIF nya sebesar 1.031. Variabel independen, keduanya memilki nilai tolerance di atas 0,10 dan nilai Variance Inflation Factors (VIP) tidak ada yang lebih besar dari 10, dapat peneliti simpulkan bahwa tidak terjadi multikolinearitas diantara variabel-variabel independen penelitian ini.

\section{Uji Heteroskedastisitas}

Pengujian ini tujuannya untuk mengetahui apakah terjadi ketidaksamaan varians dalam model regresi dari suatu pengamatan kepada pengamatan lainnya. Model regresi yang baik adalah terjdi homokedastisitas, tidak terjadinya heterokedastisitas dengan melihat grafik plot antara nilai prediksi variabel terikat (dependen) yaitu ZPRED dengan nilai residual SRESID. Adatidaknya dapat dideteksi dengan melhat apakah ada atau tidak pola tertentu dalam grafik Scatterplot antara SRESID dan ZPRED dimana sumbu Y adalah Y yang telah diprediksi, dan sumbu X adalah residual (Y prediksi - Y sesungguhnya).

\section{Gambar 1 \\ Hasil Uji Heterokedastisitas}

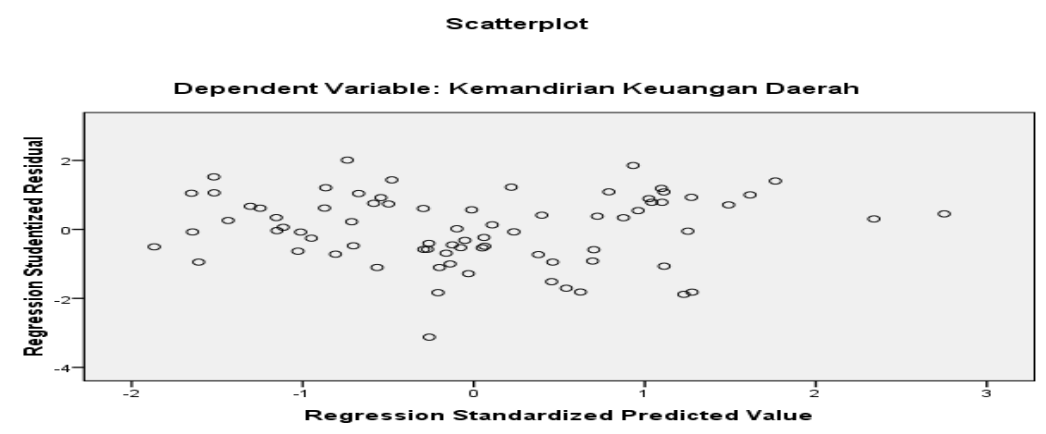

Hasil pengujian heterokedastisitas dapat peneliti simpukan tidak tejadi heterokedastisitas karena dilihat pada gambar diatas bahwa tidak ada pola yang jelas, serta titik-titik menyebar.

\section{Uji Autokorelasi}

Tujuan pengujian autokorelasi adalah menguji model regresi linear apakah ada korelasi antara kesalahan pengganggu pada periode $\mathrm{t}$ dengan periode $\mathrm{t}-1$ (sebelumnya) dimana nilai $\mathrm{D}-\mathrm{W}$ harus berada antara -2 sampai 2 agar bebas dari autokorelasi.

\section{Tabel4}

Hasil Uji Autokorelasi

\begin{tabular}{lccccc}
\hline \multicolumn{6}{c}{ Model Summary $^{\mathbf{b}}$} \\
\hline Model & $\mathrm{R}$ & R Square & $\begin{array}{c}\text { Adjusted R } \\
\text { Square }\end{array}$ & $\begin{array}{c}\text { Std. Error of the } \\
\text { Estimate }\end{array}$ & Durbin-Watson \\
\hline 1 & $.457^{\mathrm{a}}$ & .209 & .188 & .066320 & 1.084 \\
\hline \multicolumn{4}{l}{ a. Predictors: (Constant), Belanja Modal, PAD } \\
\hline \multicolumn{4}{l}{ b. Dependent Variable: Kemandirian Keuangan Daerah } \\
\hline
\end{tabular}

Sumber : Data Olahan SPSS 25 tahun 2020 
NilaiDurbin Watson (DW) terlihat dalam tabel 4 sebesar 1.084, berada antara -2 sampai +2 yaitu $-2<1.084<+2$, artinya tidak ada autokorelasi atau tidak ditemukan korelasi antara kesalahan pengganggu pada suatu periode dengan periode sebelumnya karena koefisien autokorelasi sama dengan nol dalam model regresi penelitian ini.

\section{Uji Kelayakan Model}

\section{Uji Koefisien Determinasi}

Pengujian koefisien determinasi ( $R^{2}$ ) mengukur berapa besar persentase varians yang pengaruhnya dijelaskan oleh variabel independen terhadap variabel dependen.

\begin{tabular}{|c|c|c|c|c|c|}
\hline \multicolumn{6}{|c|}{$\begin{array}{c}\text { Tabel } 5 \\
\text { Hasil Uji Koefisien Determinasi }\end{array}$} \\
\hline \multicolumn{6}{|c|}{ Model Summary ${ }^{b}$} \\
\hline Model & $\mathrm{R}$ & R Square & $\begin{array}{l}\text { Adjusted R } \\
\text { Square }\end{array}$ & $\begin{array}{l}\text { Std. Error of the } \\
\text { Estimate }\end{array}$ & Durbin-Watson \\
\hline 1 & $.457^{\mathrm{a}}$ & .209 & .188 & .066320 & 1.084 \\
\hline \multicolumn{6}{|c|}{ a. Predictors: (Constant), Belanja Modal, PAD } \\
\hline \multicolumn{6}{|c|}{ b. Dependent Variable: Kemandirian Keuangan Daerah } \\
\hline
\end{tabular}

Sumber : Data Olahan SPSS 25 tahun 2020

Nilai Adjusted $R$ Square $\left(\mathrm{R}^{2}\right)$ pada tabel 5 sebesar 0.188 yang berarti hanya sebesar $18,8 \%$ variabel independen yaitu Pendapatan Asli Daerah dan Belanja Modal mampu menjelaskan Kemandirian Keuangan Daerah, sedangkan sisanya 81,2\% dipengaruhi atau djelaskan oleh variabel lain yang tidak dimaksukkan dalam model penelitian.

\section{Uji F}

Pengujian variabel dependen untuk mengetahui apakahsecara bersamaan variabel independen mampu mempengaruhi atau menjelaskan variabel dependen dengan baik dan menguji model yang digunakan apakah telah fix atau tidak.

\section{Tabel 6}

Hasil Uji F (Simultan)

\begin{tabular}{|c|c|c|c|c|c|c|}
\hline \multicolumn{7}{|c|}{ ANOVA $^{b}$} \\
\hline Model & & Sum of Squares & $\mathrm{df}$ & Mean Square & $\mathrm{F}$ & Sig. \\
\hline \multirow[t]{3}{*}{1} & Regression & .085 & 2 & .042 & 9.655 & $.000^{\mathrm{a}}$ \\
\hline & Residual & .321 & 73 & .004 & & \\
\hline & Total & .406 & 75 & & & \\
\hline \multicolumn{7}{|c|}{ a. Predictors: (Constant), Belanja Modal, PAD } \\
\hline \multicolumn{7}{|c|}{ b. Dependent Variable: Kemandirian Keuangan Daerah } \\
\hline
\end{tabular}

Sumber : Data Olahan SPSS 25 tahun 2020

Tabel 6 menemukan bahwa kemandirian keuangan daerah diperngaruhi oleh pendapatan asli daerah dan belanja modal secara simultan, karena nilai signifikansi uji f sebesar 0.000 lebih kecil dari 0.05. Hasil uji f memenuhi kriteria sehingga dapat dilanjutkan dengan uji t. 


\section{Uji Hipotesis (t)}

Pengujian nilai signifikansi variabel bebas terhadap dengan variabel terikat dapat dilakukan dengan melakukan uji t.

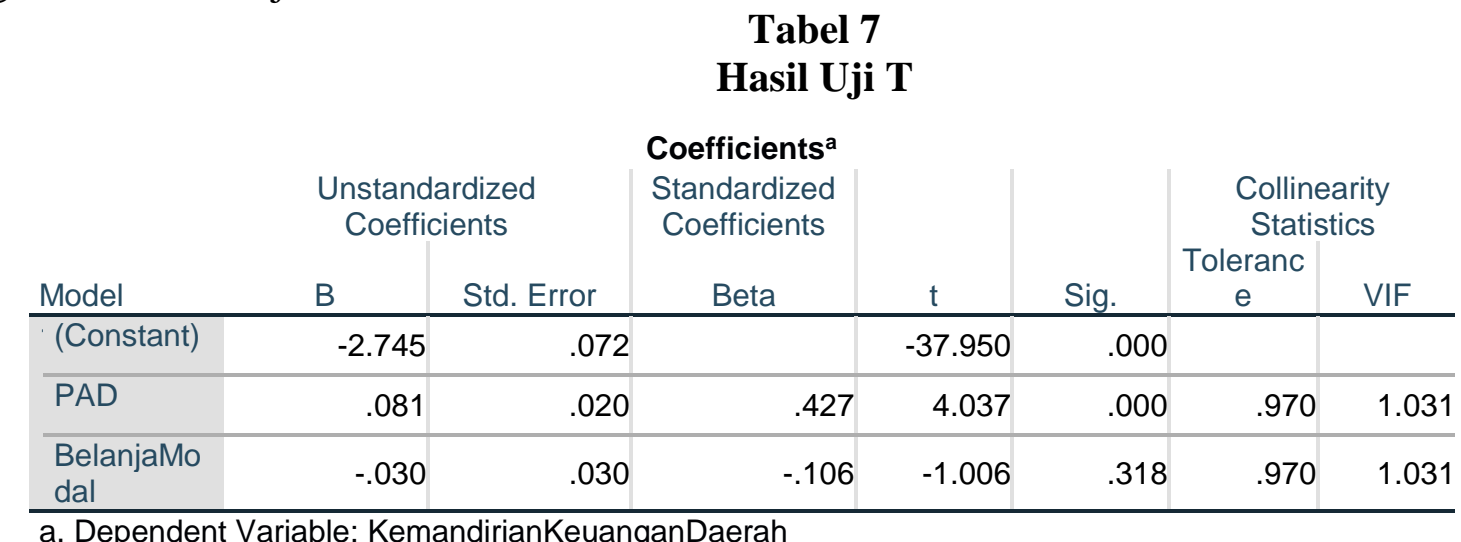

Sumber : Data Olahan SPSS 25 tahun 2020

\section{Hipotesis 1 ( Pendapatan Asli Daerah berpengaruh positif terhadap Kemandirian Keuangan Daerah)}

Variabel kemandirian keuangan daerah diperngaruhi sebesar $8,1 \%$ oleh pendapatan asli daerah secara positif karean pada tabelhasil uji tPendapatan Asli Daerah memiliki nilai sig $(0.000)<\alpha$ (0.05) dan sebesar 0.081 koefisien $\beta$ dengan arah positif, sehingga Hipotesis 1 diterima. Hipotesis 2 (Belanja Modal berpengaruh positif terhadap Kemandirian Keuangan Daerah). Variabel kemandirian keuangan daerah tidak diperngaruhi oleh belanja modal karean pada hasil tabel uji t memberikan nilai $\operatorname{sig}(0.318)>\alpha(0.05)$ dan -0.030 untuk koefisien $\beta$ dengan arah negatif, sehingga Hipotesis 2 ditolak.. Hipotesis 3 (Pertumbuhan Ekonomi Memoderasi PAD dan Belanja Modal terhadap Kemandirian Keuangan Daerah). Kemandirian Keuangan Daerah yaang diperngaruhi oleh Pendapatan Asli Daerah dan Belanja Modal tidak bisa dimoderasi oleh pertumbuhan ekonomii karena pada persamaan kedua, nilai residualdilihat dari Unstandardized coefficients Bmemilki pengaruh positif sebesar 4.222 dan 0.076 nilai signifkansnya disimpulkan bahwa Hipotesis 3 ditolak.

\section{PEMBAHASAN}

\section{Pengaruh Pendapatan Asli Daerah terhadap Kemandirian Keuangan Daerah}

Penelitian ini menemukan bukti empiris bahwa Pendapatan Asli Daerah berpengaruh positif dan signifikan terhadap kemandirian keuangan daerah pada kabupaten/kota Provinsi Sumatera Barat. Hasil pengolahan data menunjukkan bahwa nilai koefisien pendapatan asli daerah sebesar 0.081 dengan tingkat signifikansi sebesar $0.000<\alpha(0.05)$ maka dapat dismpulkan bahwa pendapatan asli daerah berpengaruh signifkan terhadap kemandirian keuangan daerah namun pengaruhnya hanya sebesar $8,1 \%$.

Rendahnya pengaruh pendapatan asli daerah disebabkan oleh rata-rata proporsi pendapatan asli daerah selama tahun 2015 sampai 2018 masih dibawah $10 \%$ dan hanya pada tahun 2017 sebesar 12.09\%, artinya semakin rendah kemampuan pemerintah daerah dalam memperoleh pendapatan asli daerah maka akan semakin keciil kontribusi PAD terhadap total pendapatan daerah sehingga kemandirian keuangan daerah juga semakin rendah. 
Penelitian ini sejalan dengan penelitian yang telah dilakukan olehApriana dan Suryanto (2010) yang meneliti pada Kabpuaten/Kota se Jawa-Bali dan penelitian Tahar dan Zakhiya (2011) yang meneliti pada Kabupaten/Kota di Pulau Kalimantan menemukan bahwa Pendapatan Asli Daerah berpengaruh terhadap Kemandirian Keuangan Daerah, akan tetapi hasil penelitian ini bertentangan dengan penelitian yang dilakukan oleh Rika Oktavianti (2016) yang menelitti pada Provinsi Daerah Istimewa Yogyakarta yang menemukan bahwa pendapatan asli daerh yang diukur dengan efektvitas PAD tidak memiliki pengaruh signifikan dengan tingkat kemandirian keuangan daerah.

\section{Pengaruh Belanja Modal terhadap Kemandirian Keuangan Daerah}

Penelitian ini menemukan bukti empiriis bahwa Belanja Modal berpengaruh negatif dan tidak signifikan terhadap kemandirian keuangan daerah pada kabupaten/kota Provinsi Sumatera Barat. Arah hubungan negatiif antara belanja modal terhadap kemandirian keuangan daerah, menunjukkan bahwa adanya hubungan yang berbanding terbalik antara belanja modal terhadap kemandirian keuangan daerah. Peningkatan belanja modal pemerintah kabupaten/kota Provinsi Sumatera Barat menyebabkan terjadnya penurunan terhadap kemandirian keuangan daerah, begitupun sebaliknya

Hasil pengujian menunjukkan bahwa Belanja Modal yang dianggarkan pemerintah daerah yang berasal dari penerimaan daerah tidak bisa meningkatkan kemandirian keuangan daerah pada kabupaten/kota Provinsi Sumatera Barat. Hasil peneltian ini tidak berpengaruh disebabkan karena alokasi belanja modall pemerintah kabupaten/kota Provinsi Sumatera Barat rata-rata sebesar $21 \%-25 \%$ dari total belanja daerah. Alokasi belanja modal yang rendah mengindkasikan bahwa kemampuan pemerintah daerah dalam membiayai kegiatan pembangunan daerah yang lemah sehingga membutuhkan bantuan dari pemerintah pusat, hal ini menyebabkkan belanja modal memiliki pengaruh negatif terhadap kemandirian keuangan daerah

Hasil penelitian ini sejalan dengan penelitian Yuliyanto (2018) dan Apriana dan Suryanto (2010) yang menemukan bahwa belanja modal berpengaruh negatif dan tidak signifikan terhadap kemandirian keuangan daerah, namun hasil penelitian ini bertolak belakang dengan penelitian yang dilakukan Sanga, et al (2018) yang menemukan bahwa Belanja Modal berpengaruh terhadap Kemandirian Keuangan Daerah.

\section{Pengaruh Pendapatan Asli Daerah dan Belanja Modal terhadap Kemandirian Keuangan Daerah dengan dimoderasi oleh Pertumbuhan Ekonomi}

Penelitian ini menemukan bukti empiiris bahwa Pendapatan Asli Daerah dan Belanja Modal tidak berpengaruh terhadap kemandirian keuangan daerah dengan dimoderasi oleh Pertumbuhan Ekonomi pada kabupaten/kota Provinsi Sumatera Barat. Hasiil ini mengindikasikan bahwa terjadnya peningkatan pertumbuhan ekonomi tidak serta merta dapat meningkatkan pendapatan asli daerah dan belanja modal sehingga kemampuan pemeriintah daerah dalam membiayai kegiatan pemerintahan tidak dpengaruhi oleh pertumbuhan ekonomi di Provinsi Sumatera Barat.

\section{SIMPULAN, KETERBATASAN DAN SARAN \\ Simpulan}

Penelitian ini memilki tujuan untuk melihat pengaruh pendapatan asli daerah dan belanja modal terhadap kemandiria keuangan daerah pada kabupaten/kota Provnsi Sumatera Barat tahun 2015 sampai dengan 2018. Pendapatan asli daera secara positif memiliki pengaruh terhadap kemandiria keuangan daerah dengan koefisien beta sebesar 0.081 dan sebesar 0.000 niali 
signfikansinya. Kemandrian keuangan daerah tidak diipengaruhi oleh belanja modal karena nilai koefisien beta -0.30 dengan signifikansnya sebsar 0.318 . Variabel moderasi yaitu peertumbuhan ekonomi yang tujuannya memoderasi pendapatan asli daerah dan belanja modal terhadap kemandrian keuangan daerah, tidak dapat mempengaruhi dijadikan sebagai variabel moderasi hal ini dikarenakan niali signifikansinya lebih besar dari yang dtetapkan .

\section{Keterbatasan}

Penelitian ini telah dikembangkan dan dirancang sedemkian rupa, tetapi masih perlu untuk direvisi oleh peneliti selanjutnya karena ada beberapa keterbatasan yaitu kemandirian keuangan daerah hanya dianalisis setelah otonomi daerah saja sehingga tidak dapat diketahui apakah setelah pelaksanaan otonomi daerah dapat meningkatkan kemandirian keuangan daerah. Peneliti tidak melakukan observasi karena hanya menggunakan data sekunder yang datanya kurang lengkap, sehingga permasalahan kemandirian keuangan tidak bisa dibahas secara keseluruhan.

\section{Saran}

Peneliti selanjutnya, kemandiria keuangan daerah dapat dibandingkan periode sebelum dengan sesudah pelaksanaan otonomi daerah, memakai metode observasi untuk memperbaharui peneliitian ini yang menggunakan data sekunder dikarenakan mash belum lengkap dan mencari variabel yang dapat memoderasi hubungan pendapatan asli daerah dan belanja modal terhadap kemandrian keuangan daerah.

\section{DAFTAR PUSTAKA}

Apriana, Dina dan Suryanto, Rudi. (2010). Analisis Hubungan Antara Belanja Modal, Pendapatan Asli Daerah, Kemandirian Keuangan Daerah dan Pertumbuhan Ekonomi Daerah (Studi pada Kabupaten dan Kota se Jawa-Bali)". Jurnal Akuntansi dan Investasi, 11(1), 68-79.

Badan Pusat Statistik Provinsi Sumatera Barat. Produk Domestik Regional Bruto. www.bpjs.go.id, diakses September 2019.

BPK Perwakilan Provinsi Sumbar. (2015- 2018). Laporan Hasil Pemeriksaan (LHP) atas Laporan Keuangan Pemerintah Daerah Kabupaten/kota di Provinsi Sumatera Barat. www.padang.bpk.go.id, diakses September 2019.

BPK Perwakilan Provinsi Sumbar. (2018). Kabupaten/Kota Diimbau Tingkatkan PAD. www.padang.bpk.go.id, diakses September 2019.

Darwis, Esterlita Tria Ramadhani.(2015).Pengaruh Beanja Modal dan BelanjaPegawai terhadap Kemandirian Keuangan Daerah Pada Kabupaten/Kota Provinsi Sumatera Barat. www.ejournal.unp.ac.id, diakses September 2019.

Davis J. H dan L. Donaldson. (1991). Stewardship Theory or Agency Theory : CEO Governance dan Shareholder Returns. Australia Jornal of Manajemen, 16(1).

Direktorat Jendral Bina Keuangan Daerah Kementerian Dalam Negeri. (2013). Belanja Modal Pemda Harus Capai 30 Persen. www.keuda.kemendagri.go.id, diakses September 2019.

Fitra, Halkadri. (2018). Modul Manajemen Keuangan Daerah. UNP.

Gaghana, dkk. (2018). PengaruhPertumbuhna Ekonomi dan Pendapatan Asli Daerah terhadap Kemandirian Keuangan Daerah. Jurnal Pembangunan Ekonomi dan Keuangan Daerah, 19(7). 
Ghozali, Imam. (2013). Aplikasi Analisis Multivariate dengan Program SPSS, Edisi ke tujuh. Semarang : Universitas Diponegoro.

Guga, Elona. (2018). Local Government Modernization in Albania : HistoricalBackground and the Territorial Reform 2015-2020. International Journal of Public Sector Management.

Halim, Abdul. (2004). Akuntansi Keuangan Daerah.. Jakarta : Salemba Empat.

Halim, Abdul. (2007). Akuntansi Keuangan Daerah. Jakarta : Salemba Empat.

Jaeni dan L, Greg Anggana. (2016). Pertumbuhan Ekonomi sebagai Variabel Pemoderasi Pendapatan Asli Daerah dan Dana Alokasi Khusus terhadap Belanja Modal. Dinamika Akuntansi, Keuangan dan Perbankan, 5(1), 13-26.

Kim, Pan S dan Young, Kim Jae. (2003). Fiscal Autonomy of Korean Local Governments and Intergovernmental Relations in the 1990S. Journal of Public Budgeting, Accounting and Financial Manajement, 15(3), 414-437.

Koo, Jun dan Kim, Byoung Joon. (2018). Two Face of Decentralization in South Korea. Asian Education and Development Studies, 7(3), 291-302.

Mahmudi. (2010). Manajemen KeuanganDaerah.Yogyakarta: Erlangga.

Mardiasmo. (2002). Otonomi dan Manajemen Keuangan Daerah. Yogyakarta:ANDI.

Mubyarto. (2001).Otonomi Daerah danPerekonomianIndonesia. Yogyakarta : BPFE

Nur'ainy, dkk. (2013). PengaruhPertumbuhan Ekonomi dan Pendapatan AsliDaerah terhadap Kemandirian Keuangan Daerah. Proceeding PESAT (Psikologi, Ekonomi, Sastra, Arsitektur \& Teknik Sipil), 5(10), 1858-2559.

Peraturan Pemerintah Nomor 71 Tahun 2010 tentang Standar Akuntansi Pemerintah.

Purbadharmaja, et al. (2018). The Implications of Fiscal Desentralization and Budget Governance on Economic Capacity and Community Welfare. Emerald Publising Limited, 1463-6689.

Raharjo. (2007).Teori Agenci dan TeoriStewardship dalam Perspektif Akuntansi. Fokus Ekonomi, 2(1), 1907-6304.

Renyaan, et al. (2010). Menganalisa Effect of Fiscal Autonomy and Economic Growth on Local Financial Performance (A Study on Local Government Of Papua Province). Skripsi. Fakultas Ekonomi. Universitas Cendrawasih. Jayapura.

Republik Indonesia. Undang-Undang Nomor 23 Tahun 2014 tentang Pemerintah Daerah.

Republik Indonesia. Undang-Undang Nomor 33 Tahun 2004 tentang Perimbangan Keuangan antara Pemerintah Pusat dan Pemerintah Daerah.

Rustiadi, Susunan Saeifulhakim dan DyahR.Pranujulu. (2009). Perencanaan dan Pengembangan Wilayah. Jakarta : $\quad$ Yayasan Obor Indonesia.

Sanga, dkk. (2018). "Pengaruh Penerimaan Daerah terhadap KemandirianKeuangan Daerah dengan Belanja Modal sebagai Variabel Intervening". Konferensi Regional Akuntansi V. www.researchgate.net

Stagliano B, S. Brunelli, S Testarmata danA. Giosi. (2014). The Dimensions of Fiscal Governance as the Cornerstone of Public Finance Sustainability A General Framework. Journal of Public Budgeting, Accounting \& Financial Management. 26 (1), 94-139.

Sugiyono. (2010). Metode Penelitian Bisnis. Bandung : Alfabeta.

Sukirno, Sadono. (2002). Pengantar Teori Makroekonomi. Jakarta : PT RajaGrafindo Persada.

Sutami, Zelfia Yuliana. (2016). Pengaruh Pendapatan Asli Daerah, Dana Alokasi Umum dan Dana Alokasi Khusus terhadap Tingkat Kemandirian Keuangan Daerah Pada Pemerintah 
Kabupaten/Kota di Provinsi Kepulauan Riau Tahun 2008-2013. Skripsi. Fakultas Ekonomi. Universitas Maritim Raja Ali Haji. Kepulauan Riau.

Syaiful. (2010). Pengertian dan Perlakuan Akuntansi Belanja Barang dan Belanja Modal Dalam Kaidah Akuntansi Pemerintahan. http://file.upi.edu/Direktori/L\%20\%20FPEB/PRODI>AKUNTANSI/196510122001121\%2 0-\%20IKIN\%20SOLIKIN/Jurnal\%20PAD.pdf.

Tolosang, Krest D. (2018). Pengaruh Pertumbuhan Ekonomi dan Pendapatan Asli Daerah terhadap Tingkat Kemandirian Keuangan Daerah Kota Tomohon. Jurnal Berkala Ilmiah Efisiensi, 18(13).

Tahar, Afrizal dan Zakhiya, Maulida. (2011). Pengaruh Pendapatan Asli Daerah dan Dana Alokasi Umum terhadap Kemandirian Daerah dan Pertumbuhan Ekonomi Daerah. Jurnal Akuntansi dan Investasi, 12(1), 88-99.

Yuliyanto, Andri. (2018). Analisis Pengaruh Pendapatan Asli Daerah, Dana Alokasi Umum, Dana Alokasi Khusus dan Belanja Modal terhadap Tingkat Kemandirian Keuangan Daerah (Studi Empiris Pada Kabupaten/Kota di Provinsi Jawa Timur Tahun 2014-2016). Publikasi Ilmiah Universitas MuhammadiyahSurakarta. 